\title{
A New Canthinone-Type Alkaloid Isolated from Ailanthus altissima Swingle
}

\author{
Hye Mi Kim ${ }^{1}$, Jin Su Lee ${ }^{2}$, Jurdas Sezirahiga ${ }^{1}$, Jaeyoung Kwon ${ }^{3}$, Miran Jeong ${ }^{2}$, Dongho Lee ${ }^{3}$, \\ Jung-Hye Choi ${ }^{1,2}$ and Dae Sik Jang ${ }^{1,2, *}$ \\ 1 College of Pharmacy, Kyung Hee University, Seoul 130-701, Korea; hyemi586@gmail.com (H.M.K.); \\ jurdas30@gmail.com (J.S.); jchoi@khu.ac.kr (J.-H.C.) \\ 2 Department of Life \& Nanopharmaceutical Sciences, Kyung Hee University, Seoul 130-701, Korea; \\ lee2649318@naver.com (J.S.L.); jeongmiran@hanmail.net (M.J.) \\ 3 Department of Biosystems and Biotechnology, College of Life Sciences and Biotechnology, Korea University, \\ Seoul 136-713, Korea; kjwkjy1207@gmail.com (J.K.); dongholee@korea.ac.kr (D.L.) \\ * Correspondence: dsjang@khu.ac.kr; Tel.: +82-2-961-0719
}

Academic Editor: Isabel C. F. R. Ferreira

Received: 16 March 2016; Accepted: 12 May 2016; Published: 16 May 2016

\begin{abstract}
The present investigation of the chemical constituents of the stem barks of Ailanthus altissima has resulted in the isolation of six canthinone-type alkaloids, including a new compound, (R)-5-(1-hydroxyethyl)-canthine-6-one (1), and five known compounds (2-6). Moreover, four phenyl propanoids (7-10), two lignans (11 and 12), two triterpenoids (13 and 14) and a fatty acid (15) having previously known chemical structures were isolated during the same course of this study. The structure of the new compound was elucidated by physical (m.p., $\left.[\alpha]_{\mathrm{D}}\right)$ and spectroscopic data $\left({ }^{1} \mathrm{H}-\mathrm{NMR},{ }^{13} \mathrm{C}-\mathrm{NMR}, 2 \mathrm{D}\right.$ NMR, and HR-DART-MS) interpretation and its absolute configuration was determined by electronic circular dichroism (ECD) data and quantum chemical calculations. The inflammatory activities of the isolates were screened on lipopolysaccharide (LPS)-induced nitric oxide (NO), a proinflammatory mediator, in RAW 264.7 cells. Among these isolated compounds, six compounds exhibited significant inhibition of $\mathrm{NO}$ production, with $\mathrm{IC}_{50}$ values in the range of $5.92 \pm 0.9$ to $15.09 \pm 1.8 \mu \mathrm{M}$.
\end{abstract}

Keywords: Ailanthus altissima; simaroubaceae; canthinone type alkaloids; nitric oxide; inflammation

\section{Introduction}

Ailanthus altissima Swingle (Simaroubaceae), the tree-of-heaven, has been used to treat diarrhea, dysentery, heat ailments, epilepsy, asthma, ophthalmic diseases, and it has also been used as an astringent. The stem bark of A. altissima has exhibited various biological activities, such as anti-proliferative, cytotoxic, anti-plasmodial, anti-malarial, anti-viral, antibacterial, anti-fungal, and analgesic activity [1,2]. Additionally, it was reported that a decoction of $A$. altissima decreased the production of inflammatory cytokines, TNF, IL- 6 and IL-8 as well as NF-KB activation on the phorbol 12-myristate 13-acetate and calcium ionophore A23187 (PMACI)-stimulated human mast cell line, HMC-1 [3]. Furthermore, the EtOH extract of A. altissima inhibited the generation of the cyclooxygenase-2 (COX2)-dependent phases of prostaglandin D2 in bone marrow-derived mast cells (BMMC) [4]. Previous phytochemical investigations of A. altissima revealed the presence of alkaloids, terpenoids, steroids, and flavonoids [5]. Among these compounds, quassinoids and indole and $\beta$-carboline alkaloids are common major constituents of A. altissima [6-8]. Alkaloids from A. altissima are reported for their anti-herpes [9] and anti-mycotic properties [10] and for their action on the rate of intestinal blood flow in rabbits [11]. Indole and $\beta$-carboline alkaloids have shown inhibitory activity on cyclic adenosine monophosphate (cAMP) phosphodiesterase [12]. Moreover, it was demonstrated 
that canthin-6-one and its derivatives have anti-proliferative and cytotoxic activity [13], leishmanicidal activity [14], and gastro-protective effects [15]. Although most $\beta$-carboline and canthin-6-one alkaloids have been reported to show diverse pharmacological effects, there are few studies regarding their anti-inflammatory effects.

Recently it was reported that some quassinoids from the stem barks of A. altissima inhibited the production of nitric oxide in RAW 264.7 cells [16]. In our continuing study to search for anti-inflammatory agents from this plant, a new canthinone-type alkaloid (1), as well as 14 known compounds (2-15), was isolated further from the EtOAc- and $\mathrm{BuOH}$-soluble fractions of the $\mathrm{EtOH}$ extract of the stem barks of A. altissima (Figure 1). Herein, this paper describes the isolation and structural elucidation of the isolates and their inhibitory effects on NO production in RAW 264.7 cells.

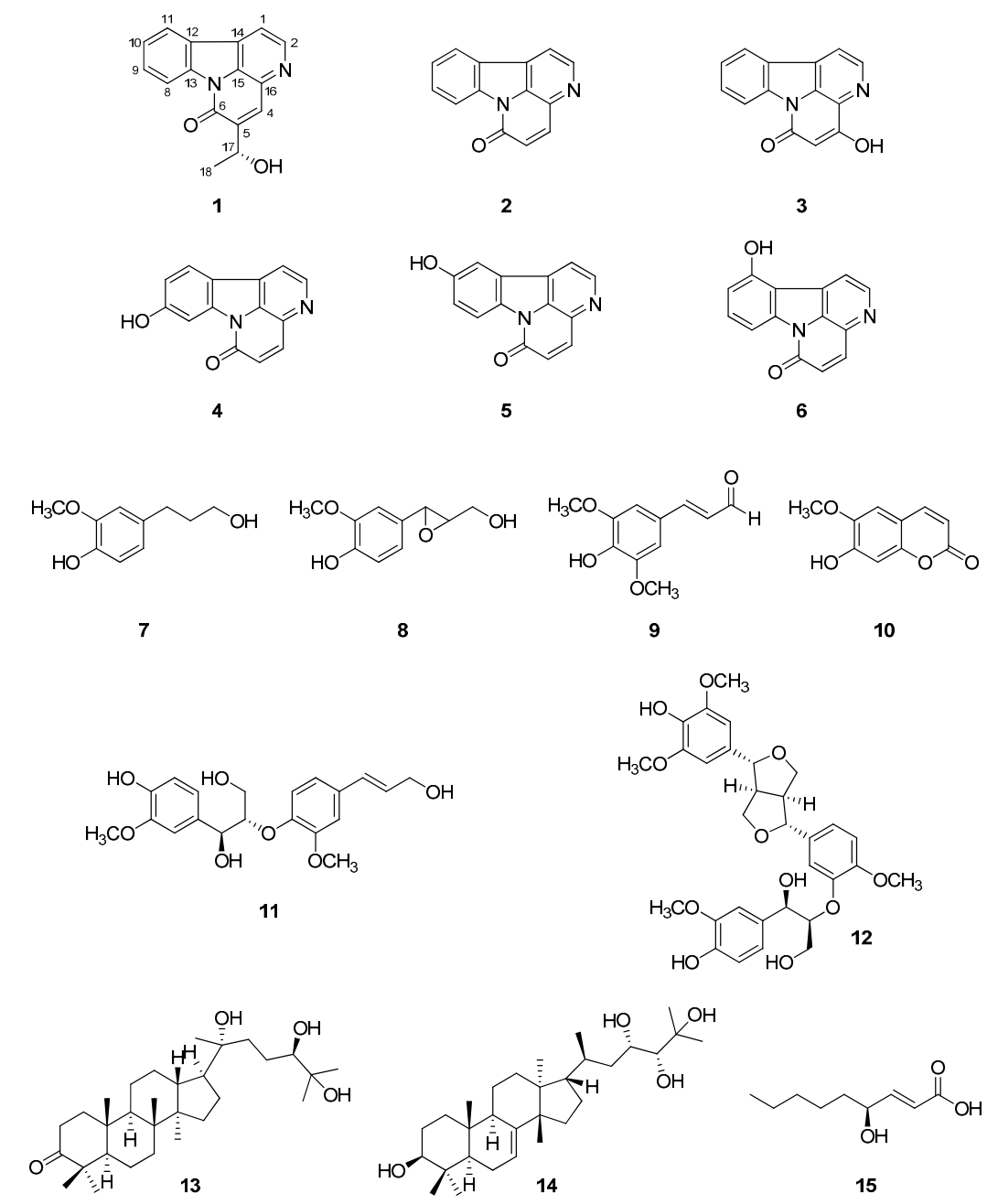

Figure 1. Structures of $\mathbf{1 - 1 5}$ isolated from the stem barks of A. altissima.

\section{Results and Discussion}

\subsection{Identification of Isolated Compounds 1-15 from the Stem Bark of A. altissima}

Compound 1 was isolated as a yellow amorphous powder, in which the molecular formula was established as $\mathrm{C}_{16} \mathrm{H}_{13} \mathrm{~N}_{2} \mathrm{O}_{2}$ by HR-DART-MS ( $m / z 265.0992[\mathrm{M}+\mathrm{H}]^{+}$; calcd. for $\mathrm{C}_{16} \mathrm{H}_{13} \mathrm{~N}_{2} \mathrm{O}_{2}$, 265.0977) (Figure S8 in Supplementary Materials). The IR spectrum indicated the presence of a hydroxyl group $\left(3159 \mathrm{~cm}^{-1}\right)$, a conjugated carbonyl group, and an aromatic ring $\left(1663,1650,1595 \mathrm{~cm}^{-1}\right.$ ) (Figure S7). The UV spectrum of 1 displayed absorption bands at 229, 258, 298, 359, and $375 \mathrm{~nm}$ (Figure S6). It was concluded to be a canthin-6-one skeleton by comparing the ${ }^{1} \mathrm{H}$ - and ${ }^{13} \mathrm{C}-\mathrm{NMR}$ data of $\mathbf{1}$ to those of 
2 (canthin-6-one) [17]. The ${ }^{13} \mathrm{C}-\mathrm{NMR}$ spectrum of $\mathbf{1}$ (Table 1 and Figure S2) showed 16 carbon signals including a methyl, eight methines, and seven quaternary carbons. In the ${ }^{1} \mathrm{H}-\mathrm{NMR}$ spectrum (Table 1 and Figure S1), seven signals were displayed in the aromatic region. The ortho-coupled signals of the $\mathrm{C}$ ring at $\delta_{\mathrm{H}} 8.16(1 \mathrm{H}, \mathrm{d}, J=5.0 \mathrm{~Hz}, \mathrm{H}-1)$ and $\delta_{\mathrm{H}} 8.77(1 \mathrm{H}, \mathrm{d}, J=5.0 \mathrm{~Hz}, \mathrm{H}-2)$ and four mutually coupled aromatic protons at $\delta_{\mathrm{H}} 8.60(1 \mathrm{H}, \mathrm{d}, J=8.0 \mathrm{~Hz}, \mathrm{H}-8), \delta_{\mathrm{H}} 7.74(1 \mathrm{H}, \mathrm{dt}, J=8.0,1.0 \mathrm{~Hz}, \mathrm{H}-9)$, $\delta_{\mathrm{H}} 7.58(1 \mathrm{H}, \mathrm{dt}, J=8.0,1.0 \mathrm{~Hz}, \mathrm{H}-10)$, and $\delta_{\mathrm{H}} 8.26(1 \mathrm{H}, \mathrm{d}, J=8.0 \mathrm{~Hz}, \mathrm{H}-11)$ were observed. The planar structure and ${ }^{1} \mathrm{H}$ - and ${ }^{13} \mathrm{C}-\mathrm{NMR}$ chemical shifts were assigned by detailed analysis of 2D NMR spectra (Figures S3, S4 and S5), in particular HMQC, COSY, and HMBC. The ${ }^{1} \mathrm{H}$ - and ${ }^{13} \mathrm{C}-\mathrm{NMR}$ of 1 exhibited strong similarity to those of $\mathbf{2}$, except for the presence of the 1-hydroxyethyl group in the $\mathrm{D}$ ring. It was supported from $\delta_{\mathrm{H}} 8.18(1 \mathrm{H}, \mathrm{d}, J=1.0 \mathrm{~Hz}, \mathrm{H}-4)$, which was long range-coupled with a $\mathrm{H}-17$ at $\delta_{\mathrm{H}} 5.16$ $(1 \mathrm{H}, \mathrm{dq}, J=6.5,1.0 \mathrm{~Hz})$, and $\delta_{\mathrm{H}} 1.57(3 \mathrm{H}, \mathrm{d}, J=6.5 \mathrm{~Hz}, \mathrm{H}-18)$. Moreover, the ${ }^{13} \mathrm{C}-\mathrm{NMR}$ signals at $\delta_{\mathrm{C}}$ $66.1(\mathrm{C}-17)$ and $\delta_{\mathrm{C}} 23.4(\mathrm{C}-18)$ of $\mathbf{1}$ were shifted downfield due to the influence of the hydroxyl group.

Table 1. ${ }^{1} \mathrm{H}-\mathrm{NMR}(500 \mathrm{MHz}),{ }^{13} \mathrm{C}-\mathrm{NMR}(125 \mathrm{MHz}), \mathrm{COSY}, \mathrm{HMBC}$ spectroscopic data for compound 1 in $\mathrm{CD}_{3} \mathrm{OD}$.

\begin{tabular}{ccccc}
\hline Position & $\delta_{\mathbf{H}}$ Mult., $(\boldsymbol{J}$ in Hz) & $\delta_{\mathbf{C}}$ & COSY & HMBC \\
\hline 1 & $8.16 \mathrm{~d}(5.0)$ & 117.6 & $\mathrm{H}-2$ & $\mathrm{H}-2$ \\
2 & $8.77 \mathrm{~d}(5.0)$ & 146.8 & $\mathrm{H}-1$ & $\mathrm{H}-1$ \\
4 & $8.18 \mathrm{~d}(1.0)$ & 133.5 & & $\mathrm{H}-17$ \\
5 & & 147.8 & & $\mathrm{H}-17, \mathrm{H}-18$ \\
6 & & 160.2 & & $\mathrm{H}-4, \mathrm{H}-17$ \\
8 & $8.60 \mathrm{~d}(8.0)$ & 118.0 & $\mathrm{H}-9$ & $\mathrm{H}-10$ \\
9 & $7.74 \mathrm{dt}(8.0,1.0)$ & 132.1 & $\mathrm{H}-8, \mathrm{H}-10$ & \\
10 & $7.58 \mathrm{dt}(8.0,1.0)$ & 127.1 & $\mathrm{H}-9, \mathrm{H}-11$ & \\
11 & $8.26 \mathrm{~d}(8.0)$ & 124.4 & $\mathrm{H}-10$ & $\mathrm{H}-9$ \\
12 & & 126.1 & & $\mathrm{H}-1, \mathrm{H}-8$, \\
13 & & 140.9 & & $\mathrm{H}-10$ \\
14 & & 131.7 & & $\mathrm{H}-\mathrm{H}, \mathrm{H}-11$ \\
15 & & 132.5 & & $\mathrm{H}-11, \mathrm{H}-4$ \\
16 & & 137.0 & & $\mathrm{H}-2$ \\
17 & $5.16 \mathrm{dq}(6.5,1.0)$ & 66.1 & $\mathrm{H}-18$ & $\mathrm{H}-4, \mathrm{H}-18$ \\
18 & $1.57 \mathrm{~d}(6.5)$ & 23.4 & $\mathrm{H}-17$ & $\mathrm{H}-17$ \\
\hline
\end{tabular}

Furthermore, the position of the 1-hydroxyethyl group was assigned by the observed HMBC correlations from $\mathrm{H}-4\left(\delta_{\mathrm{H}} 8.18\right)$ to $\mathrm{C}-6\left(\delta_{\mathrm{C}} 160.2\right) / \mathrm{C}-17\left(\delta_{\mathrm{C}} 66.1\right), \mathrm{H}-17\left(\delta_{\mathrm{H}} 5.16\right)$ to $\mathrm{C}-4\left(\delta_{\mathrm{C}} 133.5\right) / \mathrm{C}-6$ $\left(\delta_{\mathrm{C}} 160.2\right)$, and $\mathrm{C}-18\left(\delta_{\mathrm{H}} 1.57\right)$ to $\mathrm{C}-5\left(\delta_{\mathrm{C}} 147.8\right)$ (Figure 2$)$. The absolute configuration of 1 was determined by comparing the experimental and calculated CD spectra using the time-dependent density functional theory (TDDFT) method. In the experimental electronic circular dichroism (ECD) spectrum of $\mathbf{1}$, the positive cotton effect (CE) is observed at 215 and $230 \mathrm{~nm}$. As shown in Figure 3 , the calculated ECD spectrum of 1 exhibited strong positive CE around 210 and $232 \mathrm{~nm}$, similar to the experimental spectrum of $\mathbf{1}$. As a result, the absolute configuration of the hydroxyl group in $\mathbf{1}$ was determined to have an $R$-configuration. Therefore, the structure of $\mathbf{1}$ was determined as (R)-5-(1-hydroxyethyl)-canthin-6-one.

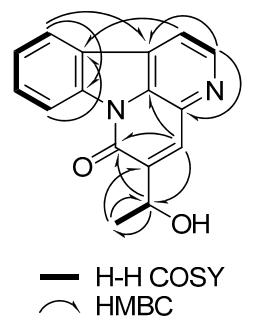

Figure 2. ${ }^{1} \mathrm{H}-{ }^{1} \mathrm{H}$ COSY and HMBC correlations of $\mathbf{1}$. 


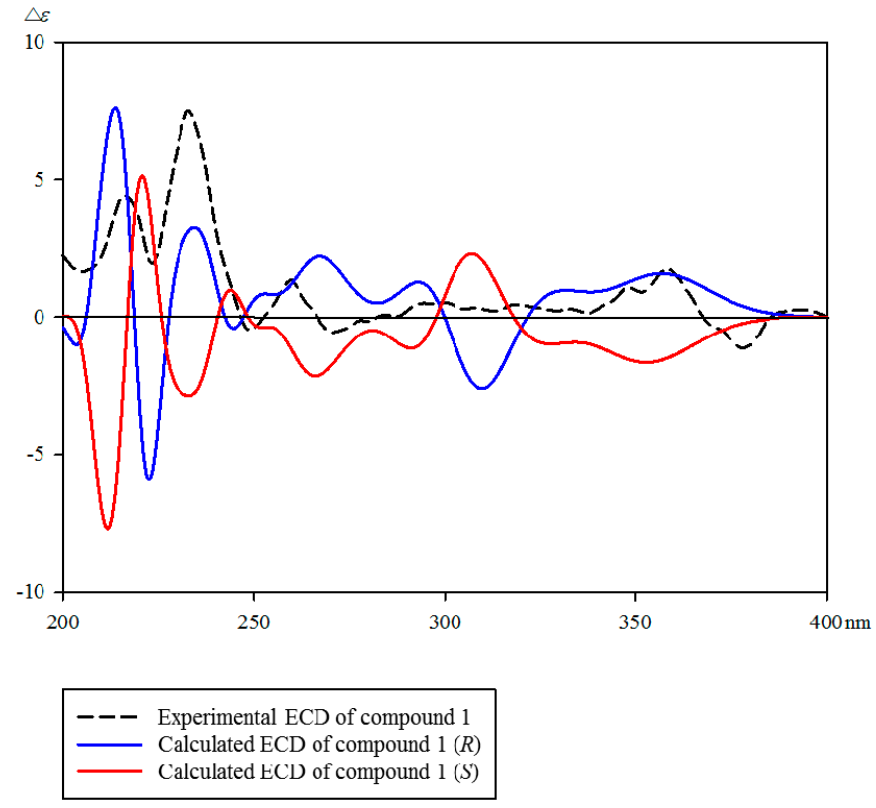

Figure 3. Experimental and calculated CD spectra of $\mathbf{1}$.

The structures of known compounds 2-15 were identified as canthin-6-one (2) [17], 4-hydroxycanthin-6-one (3) [18], 9-hydroxycanthin-6-one (4) [19], 10-hydroxycanthin-6-one (5) [20], 11-hydroxycanthin-6-one (6) [21], dihydroconiferyl alcohol (7) [22], epoxyconiferyl alcohol (8) [23], sinapaldehyde (9) [24], scopoletin (10) [25], erythro-guaiacylglycerol- $\beta-O-4^{\prime}$-coniferyl ether (11) [26], ficusesquilignan B (12) [27], 20(R)-24, 25-trihydroxy-dammaran-3-one (13) [28], hispidol B (14) [29], and trans-4(R)-hydroxy-2-nonenoic acid (15) [30] by physical (m.p., $[\alpha]_{D}$ ) and spectroscopic data $\left({ }^{1} \mathrm{H}-\mathrm{NMR},{ }^{13} \mathrm{C}-\mathrm{NMR}, 2 \mathrm{D}\right.$ NMR, and MS) measurements and by comparison with published values. Although 4-hydroxycanthin-6-one (3), 9-hydroxycanthin-6-one (4), 10-hydroxycanthin-6-one (5), and 11-hydroxycanthin-6-one (6) were isolated from the Simaroubaceae family, they have not been reported from A. altissima. Also, dihydroconiferyl alcohol (7), epoxyconiferyl alcohol (8), sinapaldehyde (9), and ficusesquilignan B (12) were isolated from this plant for the first time.

\subsection{Anti-Inflammatory Activity of Isolated Compounds 1-15 from the Stem Bark of A. altissima}

All the isolates 1-15 from the stem bark of A. altissima were evaluated for thei inhibitory effects on LPS-induced NO production in RAW 264.7 cells at non-toxic concentrations. As shown Table 2 and Figure 4, six compounds showed potent inhibitory effects on NO production ( $\mathrm{IC}_{50}$ values $\leqslant 50 \mu \mathrm{M}$ ) and were assessed using $\mathrm{IC}_{50}$ values. Among the six canthin-6-one alkaloids isolated, 11-hydroxycanthin-6-one (6) was inactive in this assay system, while (R)-5-(1-hydroxyethyl)-canthin-6-one (1), canthin-6-one (2), 9-hydroxycanthin-6-one (4) and 10-hydroxycanthin-6-one (5) exhibited inhibitory activity with $\mathrm{IC}_{50}$ values ranging from 7.73 to $15.09 \mu \mathrm{M}$. The compound 9-Hydroxycanthin-6-one (4) showed more a potent inhibitory effect than canthin-6-one $\left(2, \mathrm{IC}_{50}\right.$ value $\left.=9.09 \mu \mathrm{M}\right)$ with an $\mathrm{IC}_{50}$ value of $7.73 \mu \mathrm{M}$, indicating the hydroxylation at position 9 seems to increase the inhibitory activity. However, canthin-6-one (2) showed a more potent inhibitory effect with an $\mathrm{IC}_{50}$ value of $9.09 \mu \mathrm{M}$ than $(R)$-5-(1-hydroxyethyl)-canthin-6-one $\left(1, \mathrm{IC}_{50}\right.$ value $\left.=15.09 \mu \mathrm{M}\right)$, which has a 1-hydroxyethyl group at C-5. It was also observed that other canthin-6-one alkaloids possessing an additional hydroxyl group (5 and 6) exhibited weaker inhibitory effects than canthin-6-one (2). It seems that a hydroxyl group in canthin-6-one weakens the inhibitory effect with the exception of a hydroxyl group at C-9. However a further study is needed to ensure a structure-activity relationship for the canthin-6-one alkaloids. In a previously study, 9-hydroxycanthin-6-one (4) was reported to inhibit the NF-kB pathway in TNF-a-stimulated HEK-293/NF-kB-luc cells [31]. Among the isolates, 
sinapaldehyde (9) was found to have the most potent inhibitory effect with an observed $\mathrm{IC}_{50}$ value of $5.92 \mu \mathrm{M}$, and erythro-guaiacylglycerol- $\beta-O-4^{\prime}$-coniferyl ether (11) also showed a significant inhibitory effect with an observed $\mathrm{IC}_{50}$ value of $10.69 \mu \mathrm{M}$. By comparison with our previous study, two methoxy groups at C-3 and C-5 might be the bioactive groups for sinapaldehyde (9) [16]. Morever, sinapaldehyde (9) has shown significant inhibitory activity on TNF- $\alpha$-induced NF-KB transcriptional activity in HepG2 cells, ascribing the symmetrical methoxyl group a more important role in NF-kB inhibition [32]. However, the roles of these functional groups in the activity are not clear due to a limited number of isolates in the present study.

Table 2. Inhibitory effects of 1-15 isolated from the stem bark of $A$. altissima on nitric oxide production in LPS-induced RAW 264.7 cells.

\begin{tabular}{cccccc}
\hline Compound & $\mathrm{IC}_{\mathbf{5 0}}(\boldsymbol{\mu M}) *$ & Compound & $\mathrm{IC}_{\mathbf{5 0}}(\boldsymbol{\mu M}) *$ & Compound $^{*}$ & $\mathrm{IC}_{\mathbf{5 0}}(\boldsymbol{\mu M}) *$ \\
\hline $\mathbf{1}$ & $15.09 \pm 1.8$ & $\mathbf{6}$ & $>50$ & $\mathbf{1 1}$ & $10.69 \pm 0.4$ \\
$\mathbf{2}$ & $9.09 \pm 0.34$ & $\mathbf{7}$ & $>50$ & $\mathbf{1 2}$ & $>50$ \\
$\mathbf{3}$ & $\mathrm{ND} * *$ & $\mathbf{8}$ & $>50$ & $\mathbf{1 3}$ & $>50$ \\
$\mathbf{4}$ & $7.73 \pm 0.3$ & $\mathbf{9}$ & $5.92 \pm 0.9$ & $\mathbf{1 4}$ & $>50$ \\
$\mathbf{5}$ & $12.01 \pm 0.1$ & $\mathbf{1 0}$ & $>50$ & $\mathbf{1 5}$ & $>50$
\end{tabular}

* $\mathrm{IC}_{50}$ value is defined as the concentration that results in a $50 \%$ decreased production of nitric oxide. The values represent the means of the results from three independent experiments with similar patterns. $\mathrm{L}-\mathrm{N}^{6}$-(1-iminoethyl)lysine (L-NIL) was used as assay positive control for $\mathrm{NO}$ production ( $\mathrm{IC}_{50}$ value: $15.8 \mu \mathrm{M}$ ).

** ND: not determined due to a limited amount of the sample.

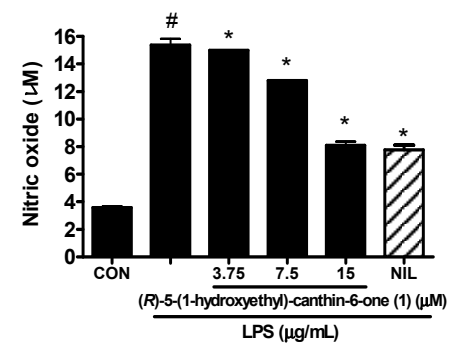

(a)

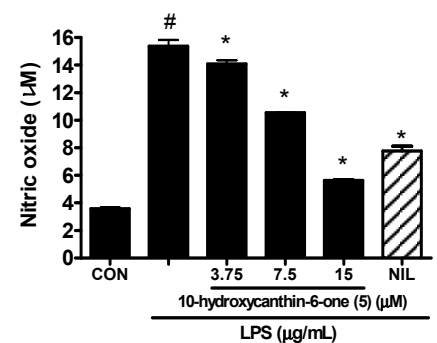

(d)

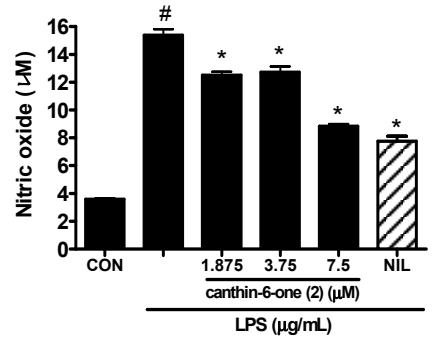

(b)

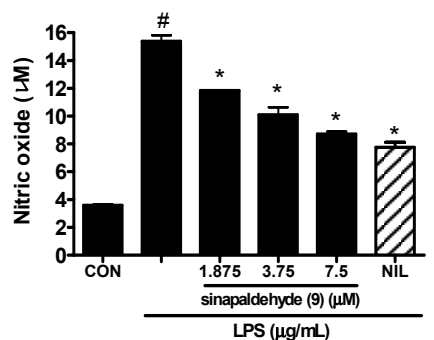

(e)

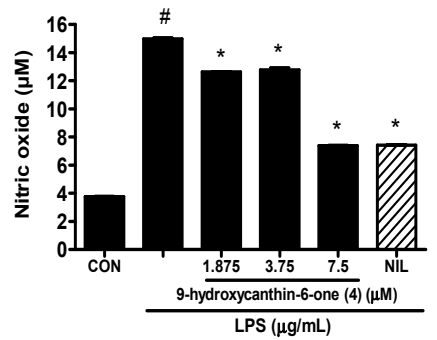

(c)

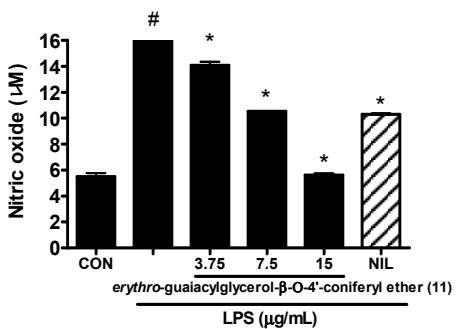

(f)

Figure 4. Effects of compounds 1 (a), 2 (b), 4 (c), 5 (d), 9 (e) and 11 (f) isolated from the stem barks of A. altissima on LPS-induced NO production in RAW 264.7 cells. Based on MTT (3-(4,5-dimethylthiazol-2-yl)-2,5-diphenyltetrazolium bromide) assay data, concentrations of isolates that would not affect cell viability were used for the following experiments. Cells were pretreated with the indicated concentrations of isolates for $1 \mathrm{~h}$ and then stimulated with LPS $(1 \mu \mathrm{g} / \mathrm{mL})$ for $24 \mathrm{~h}$. NO level in culture media was measured by Griess assay. NIL (iNOS inhibitor, $10 \mu \mathrm{M}$ ) was used as a positive control to inhibit NO production. Values represent the means \pm SD of three independent experiments. \# $p<0.05$ vs. the control group; ${ }^{*} p<0.05$ vs. LPS-stimulated group. CON, control; NIL, L-N $N^{6}$ (1-iminoethyl) lysine. 


\section{Materials and Methods}

\subsection{General Procedures}

Optical rotations were determined with a JASCO P-2000 polarimeter (Jasco Inc., Easton, MD, USA). UV and CD spectra were obtained on Spectramax M5 (Molecular Devices, Sunnyvale, CA, USA) and JASCO J-1100 spectrometers (Jasco Inc., Easton, MD, USA), respectively. IR spectra were recorded using an Agilent Cary 630 FT/IR spectrophotometer (Agilent Technologies Inc, Santa Clara, CA, USA). NMR experiments were conducted on a Varian $500 \mathrm{MHz}$, and the chemical shifts were referenced to the residual solvent signals. Chemical shift are presented in ppm. A mass spectrometer was an AccuTOF-TLC single-reflectron time-of-flight mass spectrometer equipped with a DART-SVP ion source (IonSense, Saugus, MA, USA). TLC analysis was performed on Kieselgel $60 \mathrm{~F}_{254}$ (silica gel, 0.25 mm layer thickness, Merck, Darmstadt, Germany) and RP-18 F $254 \mathrm{~S}$ (Merck) plates; compounds were visualized by dipping plates into $20 \%(v / v) \mathrm{H}_{2} \mathrm{SO}_{4}$ reagent (Aldrich, Milwaukee, WI , USA) and then heat-treated at $110{ }^{\circ} \mathrm{C}$ for 5-10 min. Silica gel (Merck 60A, 70-230 or 230-400 mesh ASTM), Sephadex LH-20 (Amersham Pharmacia Biotech), and Redi Sep-C18 (13 g, Teledyne Isco) were used for column chromatography. HPLC was performed using the Gilson Gastorr BG-34 degasser, Gilson 321 pump, Gilson UV/VIS-155 detector, with J'sphere ODS M-80 column $(250 \times 200$ mm, i.d., $4 \mu \mathrm{m})$. All solvents used for the chromatographic separations were distilled before use.

\subsection{Plant Meterial}

The stem barks of Ailanthus altissima Swingle were purchased at humanherb Co. Gyeongsangbuk-do, Gyeong-san, Korea, in November 2011. A voucher specimen (No. 2012-AIAL01) has been deposited in the Lab of Natural Product Medicine, College of Pharmacy, Kyung Hee University, Seoul, Korea.

\subsection{Extraction and Isolation}

The dried stem barks of $A$. altissima $(14 \mathrm{~kg})$ was extracted three times with $70 \% \mathrm{EtOH}$ at room temperature, and then the solution was evaporated in vacuo. The EtOH extract $(1.45 \mathrm{~kg})$ was suspended in distilled water and then partitioned with $n$-hexane, EtOAc and $\mathrm{BuOH}$, successively. A portion of the EtOAc-soluble layer (187 g) was subjected to silica gel column chromatography (CC) and eluted with a stepwise gradient of $\mathrm{CH}_{2} \mathrm{Cl}_{2}-\mathrm{MeOH}$ system (49:1 to 0:1, v/v) to afford 14 fractions (E1-E14). The fraction E4 (24.2 g) was chromatographed over silica gel (70-230 mesh) eluting with $n$-hexane-acetone (3:2 to $1: 1, v / v)$ to produce 10 subfractions (E4-1-E4-10). Fraction E4-5 (1.85 g) and E4-6 (2.58 g) were further separated using a Sephadex $\mathrm{LH}-20$ with $\mathrm{CH}_{2} \mathrm{Cl}_{2}-\mathrm{MeOH}$ mixture $(1: 1 \mathrm{v} / v)$, yielding compounds $2(9.4 \mathrm{mg}), 7(4.9 \mathrm{mg}), \mathbf{8}(11.0 \mathrm{mg}), \mathbf{9}(5.3 \mathrm{mg})$, and $10(9.5 \mathrm{mg})$. The fraction E5 $(16.04 \mathrm{~g})$ was fractionated using the silica gel CC as stationary phase with a $\mathrm{CH}_{2} \mathrm{Cl}_{2}-\mathrm{EtOAc}$ mixture $(1: 1$ to $3: 7, v / v)$ as mobile phase to afford 10 subfractions (E5-1-E5-10). Compound 14 (9.7 mg) was isolated from fraction E5-5 (2.14 g) by Sephadex LH-20 CC using mixture of $\mathrm{CH}_{2} \mathrm{Cl}_{2}-\mathrm{MeOH}(1: 1, v / v)$. The fraction E5-7 (900 mg) was successively fractionated using a Sephadex LH-20 with $\mathrm{CH}_{2} \mathrm{Cl}_{2}-\mathrm{MeOH}$ mixture $(1: 1, v / v)$ and flash chromatography system with Redi Sep-C18 (13 g, MeOH- ${ }_{2} \mathrm{O}, 13: 7$ to 1:0, 7:13 to $13: 7, v / v)$ to yield compounds $1(3.6 \mathrm{mg})$ and $12(10.6 \mathrm{mg})$. The fraction E6 $(14.0 \mathrm{~g})$ was separated by Silica gel (230-400 mesh) CC, using gradient mixtures of a $\mathrm{CH}_{2} \mathrm{Cl}_{2}$-acetone (4:1 to $\left.1: 1, v / v\right)$ as mobile phases, affording nine subfractions (E6-1-E6-9). Compounds 5 (0.7 mg) and 6 (1.4 mg) were purified from the subfraction E6-4 (1.03 g) using a Silica gel (230-400 mesh, $n$-hexane-EtOAc-MeOH, 3:2:1, $v / v)$ and preparative $\mathrm{HPLC}\left(\mathrm{MeOH}-\mathrm{H}_{2} \mathrm{O}, 1: 1\right.$ to 15:5, v/v), successively. The fraction E6-5 (1.25 g) was further fractionated using a silica gel (230-400 mesh) CC with $\mathrm{CH}_{2} \mathrm{Cl}_{2}-\mathrm{EtOH}-\mathrm{MeOH}$ mixture (9:0.9:0.1 to 7:2.7:0.3, v/v), yielding compounds $4(1.7 \mathrm{mg})$ and $5(1.1 \mathrm{mg})$. The compound 13 (9.7 $\mathrm{mg})$ was purified by recrystallization (in EtOAc) from the fraction E6-5-8 (273.1 mg). The fraction E6-7 (1.28 g) was purified further over a Sephadex LH-20 CC with $\mathrm{CH}_{2} \mathrm{Cl}_{2}-\mathrm{MeOH}$ mixture $(1: 1, v / v)$, yielding $15(7.9 \mathrm{mg})$. Compound $11(18.9 \mathrm{mg})$ was obtained from fraction E8 (190 mg) through Silica gel (230-400 mesh) CC (n-hexane-EtOAc-MeOH, 5:4:1 to 0:9:1, v/v). The BuOH-soluble layer (188 g) was 
chromatographed over silica gel CC as stationary phase with a $\mathrm{CH}_{2} \mathrm{Cl}_{2}-\mathrm{MeOH}-\mathrm{H}_{2} \mathrm{O}$ mixture (9:1:0.1 to $7: 2.8: 0.2, v / v)$ as mobile phase to afford 15 pooled fractions (B1-B15). Fraction B8 (10.07 g) was subjected to a silica gel $\mathrm{CC}$ with $\mathrm{CH}_{2} \mathrm{Cl}_{2}-\mathrm{MeOH}$ mixture (17:3 to 0:1, $\left.v / v\right)$ to produce 6 subfractions (B8-1-B8-6). Compound 3 (1.1 mg) was purified from the subfraction B8-6 (600 mg) using a Sephadex LH-20 $\left(\mathrm{CH}_{2} \mathrm{Cl}_{2}-\mathrm{MeOH}, 1: 1\right.$ to $\left.0: 1, v / v\right)$ and preparative HPLC $(0.1 \%$ formic acid in MeCN- $0.1 \%$ formic acid in $\left.\mathrm{H}_{2} \mathrm{O}, 23: 77, v / v\right)$, successively.

\subsection{Spectral Data}

(R)-5-(1-Hydroxyethyl)-canthine-6-one (1): Yellow amorphous powder; $[\alpha]_{\mathrm{D}}^{25}-13.68^{\circ}$ (c $\left.0.01, \mathrm{MeOH}\right)$; UV (MeOH) $\lambda_{\max }(\log \varepsilon) 229$ (4.54), 258 (4.35), 298 (4.21), 359 (4.32), 375 (4.27) nm; IR (ATR) $v_{\max }$ $3159,2925,1663,1650,1595,1440,1278,1225,1020,746 \mathrm{~cm}^{-1} ;{ }^{1} \mathrm{H}$ - and ${ }^{13} \mathrm{C}-\mathrm{NMR}$ data, see Table 1; HR-DART-MS (positive mode) $m / z 265.1006[\mathrm{M}+\mathrm{H}]^{+}$; calcd. for $\mathrm{C}_{16} \mathrm{H}_{13} \mathrm{~N}_{2} \mathrm{O}_{2}$, 265.0977).

\subsection{Computational Methods}

The conformational analysis was performed with Spartan'14 software package [33]and geometry optimizations were operated by the Gaussian 09 package [34]. TDDFT CD calculations for the optimized conformers were performed at the CAM-B3LYP/SVP level with a CPCM solvent model in MeCN. The CD spectra were generated by SpecDis 1.62 software [35].

\subsection{Materials}

Dulbecco's modified Eagle's minimum essential medium (DMEM), fetal bovine serum (FBS), penicillin, and streptomycin were obtained from Life Technologies Inc. (Grand Island, NY, USA). 3-(4,5-Dimethylthiazol-2-yl)-2,5-diphenyl-tetrazo-liumbromide (MTT), L-N $N^{6}$-(1-iminoethyl)lysine (L-NIL), LPS (Escherichia coli, serotype 0111:B4), and all other chemicals were purchased from Sigma Chemical Co.(St. Louis, MO, USA).

\subsection{Cell Culture and Sample}

RAW 264.7 macrophages were obtained from the Korea Cell Line Bank (Seoul, Korea). Cells were grown at $37^{\circ} \mathrm{C}$ in DMEM medium supplemented with $10 \%$ FBS, penicillin sulfates in a humidified atmosphere of $5 \% \mathrm{CO}_{2}$. Cells were pretreated with isolated compounds from A. altissima $(7.5 \mu \mathrm{M} / \mathrm{mL})$ or positive controls (L-NIL for iNOS inhibitor) for $1 \mathrm{~h}$, and then stimulated with LPS $(1 \mu \mathrm{g} / \mathrm{mL})$ for the indicated time.

\subsection{Cell Viability Assay}

Cell viability studies were performed using the MTT (3-[4,5-dimethylthiazol-2yl]-2,5-dipheyl tetrazoliumbromide; Sigma-Aldrich, St. Louis, MO, USA) assay. Raw 264.7 cells were plated at a density of $0.9 \times 10^{5}$ cells $/ \mathrm{mL}$ in 96-well. Cells were pretreated with isolated compounds from A. altissima $(50 \mu \mathrm{M})$ for $1 \mathrm{~h}$ and then stimulated with LPS $(1 \mu \mathrm{g} / \mathrm{mL})$ for $24 \mathrm{~h}$. Then $50 \mu \mathrm{L}$ of MTT solution $\left(5 \mathrm{mg} / \mathrm{mL}\right.$ in PBS) was added to the medium and the cells were incubated at $37{ }^{\circ} \mathrm{C}$ for $4 \mathrm{~h}$. The MTT-containing medium was removed and the cells were solubilized in DMSO $(100 \mu \mathrm{L})$ for $10 \mathrm{~min}$. The optical density at $540 \mathrm{~nm}$ was determined using a microplate spectrophotometer (Molecular Devices Inc., Sunnyvale, CA, USA) to determine the cell viability.

\subsection{Measurment of Nitric Oxide Production}

RAW264.7 cells were plated at $2 \times 10^{5}$ cells/well in $60 \mathrm{~mm}$ dishes and incubated with or without LPS $(1 \mu \mathrm{g} / \mathrm{mL})$ in the absence or presence of indicate concentration of the samples for $24 \mathrm{~h}$. The nitrite which accumulated in culture medium was measured as an indicator of NO production according to the Griess reagent. The culture supernatant $(100 \mu \mathrm{L})$ was mixed with $100 \mu \mathrm{L}$ of Griess reagent [equal volumes of $1 \%(w / v)$ sulfanilamide in $5 \%(v / v)$ phosphoric acid and $0.1 \%(w / v)$ naphthyl 
ethylenediamine- $\mathrm{HCl}$ ] for $10 \mathrm{~min}$, and then the absorbance at $540 \mathrm{~nm}$ was measured in a microplate reader. Fresh culture medium was used as the blank in all experiments. The amount of nitrite in the samples was determined with reference to a sodium nitrite standard curve.

\section{Conclusions}

The new canthin-6-one alkaloid (1) and 14 known compounds (2-15) were isolated from the stem bark of $A$. altissima. The structure of the new compound (1) was elucidated by its physical and spectroscopic data, and its absolute configuration was determined by comparison of its experimental and calculated ECD spectra. Compounds 3-9 and 12 were isolated from this plant for the first time. The isolates were screened for inhibitory activity against LPS-induced NO production in RAW 264.7 cells. Compounds 1, 2, 4, 5, 9 and 11 exhibited a significant inhibitory activity, with $\mathrm{IC}_{50}$ values in the range of $5.92 \pm 0.9$ to $15.09 \pm 1.8 \mu \mathrm{M}$. Thus, the active isolates seem to be worthy of additional biological tests to more fully evaluate the plant's potential as a therapeutic agent for anti-inflammatory diseases with an excess production of NO.

Supplementary Materials: Supplementary materials can be accessed at: http://www.mdpi.com/1420-3049/ 21/5/642/s1.

Acknowledgments: This work was supported by the Bio-Synergy Research Project (NRF-2014M3A9C4066594) of the Ministry of Science, ICT, and Future Planning through the National Research Foundation and by High Value-added Food Technology Development Program, Korea Institute of Planning and Evaluation for Technology in Food, Agriculture, Forestry, and Fisheries (113036-04-1-HD020).

Author Contributions: D.S.J., D.L. and J.-H.C. conceived and designed the experiments; H.M.K., J.S.L., J.S., M.J. and J.K. performed the experiments and analyzed the data; H.M.K. wrote the paper.

Conflicts of Interest: The authors declare no conflict of interest.

\section{References}

1. Howard, J.L. Ailanthus altissima; Fire Effects Information System, U.S. Department of Agriculture, Forest Service, Rocky Mountain Research Station, Fire Sciences Laboratory: Fort Collins, CO, USA, 2004. Available online: http:/ / www.fs.fed.us/database/feis/ (accessed on 15 June 2014).

2. Kowarik, I.; Säumel, I. Biological flora of central Europe: Ailanthus altissima (Mill.) swingle. Perspect. Plant Ecol. 2007, 8, 207-237. [CrossRef]

3. Jin, M.H.; Yook, J.; Lee, E.; Lin, C.X.; Quan, Z.; Son, K.H.; Bae, K.H.; Kim, H.P.; Kang, S.S.; Chang, H.W. Anti-inflammatory activity of Ailanthus altissima in ovalbumin-induced lung inflammation. Biol. Pharm. Bull. 2006, 29, 884-888. [CrossRef] [PubMed]

4. Kang, T.-H.; Choi, I.-Y.; Kim, S.-J.; Moon, P.-D.; Seo, J.-U.; Kim, J.-J.; An, N.-H.; Kim, S.-H.; Kim, M.-H.; Um, J.-Y. Ailanthus altissima swingle has anti-anaphylactic effect and inhibits inflammatory cytokine expression via suppression of nuclear factor-kb activation. In Vitro Cell. Dev. Biol. Anim. 2010, 46, 72-81. [CrossRef] [PubMed]

5. Sladonja, B.; Sušek, M.; Guillermic, J. Review on Invasive Tree of Heaven (Ailanthus altissima (Mill.) Swingle) Conflicting Values: Assessment of Its Ecosystem Services and Potential Biological Threat. J. Environ. Manag. 2015, 56, 1009-1034. [CrossRef] [PubMed]

6. Kubota, K.; Fukamiya, N.; Hamada, T.; Okano, M.; Tagahara, K.; Lee, K.H. Two new quassinoids, ailantinols A and B, and related compounds from Ailanthus altissima. J. Nat. Prod. 1996, 59, 683-686. [CrossRef] [PubMed]

7. Ohmoto, T.; Koike, K. Studies on the constituents of Ailanthus altissima SWINGLE. III. The alkaloidal constituents. Chem. Pharm. Bull. 1984, 32, 170-173. [CrossRef]

8. Souleles, C.; Waigh, R. Indole alkaloids of Ailanthus altissima. J. Nat. Prod. 1984, 47, 741-741. [CrossRef]

9. Ohmoto, T.; Koike, K. Antiherpes activity of Simarou-baceae alkaloids in vitro. Shoyakugaku Zasshi 1988, 42, 160-162.

10. Ohmoto, T.; Sung, Y.I. Antimycotic substances in the crudedrugs. II. Shoyakugaku Zasshi 1982, 36, 307-314.

11. Ohmoto, T.; Sung, Y.I.; Koike, K.; Nikaido, T. Effect of alkaloids of simaroubaceous plants on the local lood flow rate. Shoyakugaku Zasshi 1985, 39, 28-34. 
12. Ohmoto, T.; Nikaido, T.; Koike, K.; Kohda, K.; Sankawa, U. Inhibition of adenosine $3^{\prime}, 5^{\prime}$-cyclic mono-phosphate phosphodiesterase by alkaloids. II. Chem. Pharm. Bull. 1988, 36, 4588-4592. [CrossRef] [PubMed]

13. Kožuharova, E.; Lebanova, H.; Getov, I.; Benbassat, N.; Kochmarov, V. Ailanthus altissima (Mill.) Swingle-A terrible invasive pest in Bulgaria or potential useful medicinal plant? Rev. Pap. Bothalia 2014, 44, $213-230$.

14. Ferreira, M.E.; De Arias, A.R.; De Ortiz, S.T.; Inchausti, A.; Nakayama, H.; Thouvenel, C.; Hocquemiller, R.; Fournet, A. Leishmanicidal activity of two canthin-6-one alkaloids, two major constituents of Zanthoxylum chiloperone var. angustifolium. J. Ethnopharmacol. 2002, 80, 199-202. [CrossRef]

15. De Souza Almeida, E.S.; Cechinel Filho, V.; Niero, R.; Clasen, B.K.; Balogun, S.O.; de Oliveira Martins, D.T. Pharmacological mechanisms underlying the anti-ulcer activity of methanol extract and canthin-6-one of Simaba ferruginea A. St-Hil. in animal models. J. Ethnopharmacol. 2011, 134, 630-636. [CrossRef] [PubMed]

16. Kim, H.M.; Kim, S.J.; Kim, H.Y.; Ryu, B.; Kwak, H.; Hur, J.; Choi, J.-H.; Jang, D.S. Constituents of the stem barks of Ailanthus altissima and their potential to inhibit LPS-induced nitric oxide production. Bioorg. Med. Chem. Lett. 2015, 25, 1017-1020. [CrossRef] [PubMed]

17. Koike, K.; Ohmoto, T. Carbon-13 Nuclear Magnetic Resonance Study of Canthin-6-one Aalkaloids. Chem. Pharm. Bull. 1985, 33, 5239-5244. [CrossRef]

18. Crespi-Perellino, N.; Guicciardi, A.; Malyszko, G.; Arlandini, E.; Ballabio, M.; Minghetti, A. Occurrence of indole alkaloids in Ailanthus altissima cell cultures. J. Nat. Prod. 1986, 49, 1010-1014. [CrossRef]

19. Kardono, L.B.; Angerhofer, C.K.; Tsauri, S.; Padmawinata, K.; Pezzuto, J.M.; Kinghorn, A.D. Cytotoxic and antimalarial constituents of the roots of Eurycoma longifolia. J. Nat. Prod. 1991, 54, 1360-1367. [CrossRef] [PubMed]

20. Arisawa, M.; Kinghorn, A.D.; Cordell, G.A.; Farnsworth, N.R. Plant anticancer agents. XXIV. Alkaloid constituents of Simaba multiflora. J. Nat. Prod. 1983, 46, 222-225. [CrossRef] [PubMed]

21. Ouyang, Y.; Koike, K.; Ohmoto, T. Canthin-6-one alkaloids from Brucea mollis var. tonkinensis. Phytochemistry 1994, 36, 1543-1546. [CrossRef]

22. Teutonico, R.A.; Dudley, M.W.; Orr, J.D.; Lynn, D.G.; Binns, A.N. Activity and accumulation of cell division-promoting phenolics in tobacco tissue cultures. Plant Physiol. 1991, 97, 288-297. [CrossRef] [PubMed]

23. Kostova, I.; Dinchev, D.; Mikhova, B.; Iossifova, T. Epoxyconiferyl alcohol from Fraxinus oxycarpa bark. Phytochemistry 1995, 38, 801-802. [CrossRef]

24. Zhang, M.; Zhou, Z.Y.; Ren, H.; Tan, J.W.; Wan, F.H. Phenolic compounds from Eupatorium adenophorum Spreng. J. Trop. Subtrop. Bot. 2013, 21, 63-68.

25. Wang, Y.; Zhang, H.; Wang, W.; Zhang, S.; Zhang, X.; Ye, W. Chemical constituents from barks of Ailanthus altissima. Zhong Cao Yao 2012, 43, 649-652.

26. Matsutomo, T.; Stark, T.D.; Hofmann, T. In vitro activity-guided identification of antioxidants in aged garlic extract. J. Agric. Food Chem. 2013, 61, 3059-3067. [CrossRef] [PubMed]

27. Li, Y.C.; Kuo, Y.H. Four new compounds, ficusal, ficusesquilignan A, B, and ficusolide diacetate from the heartwood of Ficus microcarpa. Chem. Pharm. Bull. 2000, 48, 1862-1865. [CrossRef] [PubMed]

28. Wang, L.; Zhao, J.; Tang, W.; Wang, X. A new dammatane-type triterpene from root barks of Ailanthus altissima. Zhong Cao Yao 2014, 45, 161-163.

29. Jolad, S.D.; Hoffmann, J.J.; Schram, K.H.; Cole, J.R.; Tempesta, M.S.; Bates, R.B. Constituents of Trichilia hispida (Meliaceae). 4. Hispidols A and B, two new tirucallane triterpenoids. J. Org. Chem. 1981, 46, 4085-4088. [CrossRef]

30. Mu, L.H.; Qiang-Feng, J.; Liu, P.; Hu, Y.; Zhao, H.X. Chemical constituents of the roots of Pottsia laxiflora. Chem. Nat. Compd. 2013, 48, 1004-1007. [CrossRef]

31. Tran, T.V.A.; Malainer, C.; Schwaiger, S.; Atanasov, A.G.; Heiss, E.H.; Dirsch, V.M.; Stuppner, H. NF-kB Inhibitors from Eurycoma longifolia. J. Nat. Prod. 2014, 77, 483-488. [CrossRef] [PubMed]

32. Sun, Y.N.; Li, W.; Song, S.B.; Yan, X.T.; Yang, S.Y.; Kim, Y.H. NF-kB Inhibitory Activities of Phenolic and Lignan Components from the Stems of Acanthopanax divaricatus var. albeofructus. Nat. Prod. Sci. 2014, 20, 232-236.

33. Spartan'14; Wavefunction Inc.: Irvine, CA, USA, 2014. 
34. Frisch, M.J.; Trucks, G.W.; Schlegel, H.B.; Scuseria, G.E.; Robb, M.A.; Cheeseman, J.R.; Scalmani, G.; Barone, V.; Mennucci, B.; Petersson, G.A.; et al. Gaussian 09, Revision D.01; Gaussian Inc.: Wallingford, CT, USA, 2013. Gaussian Inc.: Wallingford, CT, USA, 2013.

35. SpecDis; Version 1.64; University of Wuerzburg: Wuerzburg, Germany, 2015.

Sample Availability: Not available. article distributed under the terms and conditions of the Creative Commons Attribution (CC-BY) license (http://creativecommons.org/licenses/by/4.0/). 